\title{
Improvement in quantifying debris flow risk for post-wildfire emergency response
}

\author{
Jerome V De Graff ${ }^{1,2}$
}

\begin{abstract}
Floods and debris flows are recognized post-fire responses to rainfall within burned watersheds. The ability of debris flows to travel rapidly over significant distances from the area of initiation and their destructive force make them a hazard of particular concern. Individuals and organizations responsible for infrastructure, property, and public safety along the potential path of post-fire debris flows must understand the risk posed in order to design and implement suitable mitigating measures. Effective mitigation necessitates a rapid assessment of risk because only weeks or months separate the wildfire incident and the possible occurrence of a debris-flow initiating storm event. In the mountainous western United States, better risk assessment is crucial due to the combination of an expanding wildland-urban interface and more frequent large wildfires. Over the last 30 years, technological improvements in mapping fire effects, advances in our scientific understanding of post-fire debris flow occurrence, and development of empirical models to predict debris flow probability and volume have improved quantification of debris flow risk and facilitated more effective debris flow mitigation. How these advances have improved emergency response assessment efforts is exemplified by comparing assessment of debris flow risk for two large wildfires which occurred 26 years apart and affected much of the same area in the Sierra Nevada of California.
\end{abstract}

Keywords: Debris flows; Wildfires; Western United States; Prediction; Models; Emergency response

\section{Introduction}

Satellite imagery has given us a greater perspective of the widespread annual occurrence of fire within the environment (NASA 2011). Some human-caused fires are accidently ignited while others are intentionally started as part of agricultural practices or arson. A significant proportion of fires worldwide result from natural ignition sources primarily lightning strikes (De Graff et al. 2013). Wildfires are a natural hazard with very immediate and potentially life-threatening consequences whether caused by human activities or due to natural events (McCaffrey 2004).

The adverse consequences of many natural hazards take place quickly over a relatively short time period ranging from minutes to days. For example, after a typhoon moves on, damage from wind stops, coastal storm surge drops, and flood flows activated by intense rainfall begin to diminish. Similarly, the immediate threat to life and structures being burned to the ground by a wildfire is over

\footnotetext{
Correspondence: jdegraff@csufresno.edu

${ }^{1}$ USDA Forest Service, 1600 Tollhouse Road, Clovis, CA 93611, USA

${ }^{2}$ Present address: Department of Earth \& Environmental Sciences, Fresno
}

State, 2576 East San Ramon Ave. M/S ST24, Fresno, CA 93740, USA when the fire front has passed through an area. However, the burned landscape is fire-altered in ways that can give rise to floods and debris flows during precipitation events occurring within a few days to as much as two years afterwards (Cannon and DeGraff 2009; Santi et al. 2013; De Graff et al. 2013). A significant body of research in the United States, Canada, Portugal, Spain, Italy, Greece, Israel, Australia and South Africa now serves as a basis for characterizing these later precipitationinitiated natural hazards (Inbar et al. 1998; Shakesby and Doerr 2006; Calcaterra et al. 2007; Jordan and Covert 2009; Nyman et al. 2011; Santi et al. 2013; Moody et al. 2013; Garćia-Ruiz et al. 2013).

Both the wildfires and related later hazards such as floods and debris flows are a significant concern within the western United States as a result of land ownership, climatic influence on wildfire occurrence and recent trends in population growth. Forty-seven percent of all land owned by the federal government is found in the 11 conterminous western states (Gorte et al. 2012). These lands are concentrated within the mountainous areas across this region. These lands are administered primarily 
by four land management agencies: Forest Service, Fish and Wildlife Service, Bureau of Land Management, and National Park Service. Management of this land is mainly for preservation, recreation, and development of natural resources (Gorte et al. 2012). These agencies are also responsible for fire prevention, fire suppression, and restoration of burned areas. Initial assessment of burned areas is typically carried out by agency specialists on Burned Area Emergency Response (BAER) teams (De Graff et al. 2007).

Of the 20 largest wildfires in California since 1932, 17 fires averaging 72,744 ha in size have occurred between 1985 to present (Cal Fire 2014). Similarly, Westerling et al. (2006) note an abrupt shift about the mid-1980s in the regime of infrequent large wildfires typically lasting a week to much more frequent ones burning for 5 weeks based on data across the western United States. Analysis of the energy release component (ERC) of the national fire danger rating system indicates the western United States will experience in the near term an increase in the number days when the ERC is above the value associated with many of the largest and most expense wildfires (Brown et al. 2004). Thus, a shift to more frequent large wildfires in the western United States appears to be the norm for the foreseeable future.

In addition to having a greater number of large fires, there is a trend for greater encroachment and population growth in close proximity to these rural areas (wildlands) subject to wildfires which, in turn, increases the elements-at-risk (Keeley et al. 1999; Radeloff et al. 2005). Consequently, the period of 1985 to 2014 has seen the general risk for post-fire debris flow impact rise for the western United States. This higher level of risk is a consequence of both the greater hazard due to more frequent large wildfires and an increase in elements-atrisk present, due to population growth with its associated infrastructure in closer proximity to wildland areas (Murnane 2006; Cannon and DeGraff 2009).

Debris flows after wildfires pose a hazard of special concern to emergency response planners, government entities, and land managers (De Graff et al. 2007). While water floods and debris flows typically follow the existing channel network, debris flows behave as a viscous mass which is capable of achieving high velocities and transporting large woody and rock debris (Pierson 2005; Restrepo et al. 2008). Consequently, debris flows are capable of inflicting damage or destruction by impact, inundation or burial along their flow path with very little warning. This destructive capability is compounded by the long distance from their sources areas that channelized debris flows may travel within a burned area. In some instances, this distance may range from 0.7 to $23.0 \mathrm{~km}$ and result in flows passing beyond the burn perimeter into adjacent unburned areas (Giraud and McDonald 2007; De Graff et al.
2011). Debris flow impacts not only can affect areas beyond the burned area perimeter but frequently take place up to 2 years after the fire has occurred (Wagner et al. 2013).

Within the general concern for public safety, infrastructure and economic wellbeing, there are well-documented examples illustrating why this post-fire phenomena is a particular concern to the emergency response community. Debris flows that occurred near San Bernardino, California after the 2003 Olds and Grand Prix fire illustrate the threat to public safety. A major storm event happened only months after the fire was contained and triggered sixtyeight debris flows including two which were responsible for sixteen fatalities within the burned canyons (Restrepo et al. 2008; Santi et al. 2011). These deaths occurred despite evacuation of campgrounds and widespread warning efforts prior to the storm.

Roads within the mountainous western United States are a common infrastructure that is threatened by postfire debris flows. Debris flows from the area burned during the 1994 South Canyon Fire in the mountains of western Colorado blocked a 4.8-kilometer length of U.S. Interstate 70 before entering the Colorado River (Cannon et al. 1998). The debris flows engulfed 30 cars and pushed some into the river. While this major transportation route was blocked for a day, the debris flow occurrence did not result in any fatalities (Cannon et al. 1998, 2001).

The economic impact of debris flows from burned watersheds is not limited to structural loss and damage within the fire perimeter. The same storm event responsible for the fatalities within the perimeter of the 2003 Olds and Grand Prix fire generated 4.1 million cubic meters of debris. The debris was captured within constructed basins which protect the heavily urbanized area outside the fire perimeter near the mountain front and required US\$9.5 million for later removal and disposal (Cannon and Gartner 2005).

Effective mitigation of post-fire debris flow impacts requires rapid assessment of the risk they pose. This is one reason why BAER teams are directed to identify both element-at-risk from debris flows and proposed mitigation measures within 10 day after containment of the wildfire. At its simplest, risk represents the product of the probability of a hazard event occurring and the elementsat-risk (their vulnerability and value) from such an occurrence (Varnes 1984; van Westen et al. 2006). Consequently, mitigation is dependant on knowing the likelihood and location of possible debris flows to define the potential hazard. Effective mitigation also requires identifying the elements-at-risk, i.e., people, structures, infrastructure, natural resources, ecological habitat, which may be destroyed, damaged or functionally impaired by debris flows. The elements-at-risk also will have varying degrees of vulnerability to the destructive force of debris flows ranging from 
complete loss to minor damage. The post-fire risk posed by debris flows will be the product of the defined hazard for all elements-at-risk. Defining the risk facilitates comparing different mitigation strategies for their potential cost and benefit and pinpoints constraints important to designing mitigation measures.

The uncertainty involved in forecasting debris-flow initiating storm events is another reason for quickly conducting risk assessments. Debris flow occurrence will be triggered by precipitation during storm events. Many wildfires happen during the months just prior to the first seasonal rainy period. Cannon et al. (2011) documents a number of California wildfires occurring during July through November where debris flows were triggered by storms taking place 1 to 6 months later. The stormrelated uncertainty would be reduced if the risk of postfire debris flows can linked to a particular rainfall intensity - duration threshold (Cannon et al. 2011; Kean et al. 2011). Such a threshold would provide a means for predicting when evacuation and similar mitigations might be implemented. Consequently, risk assessment must take place quickly to ensure sufficient time remains to plan, design, and implement mitigation measures before a possible triggering storm.

This paper will examine how rapid assessment of debris flow risk after a wildfire has improved over the last 30 years. Two large wildfires occurring twenty-six years apart and affecting much of the same area in the Sierra Nevada, California provide a framework for this review analysis. We will focus on how technological advances coupled with an improved scientific understanding of the post-fire debris flow initiation mechanisms has promoted quantifying the risk from debris flows following wildfires. We will also examine how this improved predictive capability influenced risk determination for large burned areas with post-fire debris flow potential.

\section{Review}

\section{The two wildfires}

The 1987 Stanislaus Complex Fire and the 2013 Rim Fire primarily burned land administered by the Federal government within the Stanislaus National Forest and, to a much lesser extent, Yosemite National Park within the southern Sierra Nevada, California. The areas encompassed by the two fires are within the drainages of the Tuolumne and Merced rivers (Figure 1). The Stanislaus Complex fire was ignited by lightning on August 29, 1987 with containment achieved on September 21, 1987. The Rim fire started due to an illegal campfire on August 17, 2013 with containment achieved on October 1, 2013.

Emergency response for both fires included deploying BAER teams prior to containment of the fire due to the significant amount of public land burned. The teams were responsible for assessing how the burned drainage basins might respond to future storm events, identifying risk to public safety, property, and the environment, and proposing mitigation measures to be undertaken for risk reduction (De Graff and Lewis 1989; Gallegos et al. 2013).

Geologists on a BAER team focus on the specific risk posed by geologic hazards such as debris flows, rockfall and other landslides within the burned area (De Graff et al. 2007, 2011; De Graff and Gallegos 2012). Typical elements-at-risk potentially affected by debris flows include roads, hydroelectric facilities, telecommunication sites, pipelines for water systems and energy transmission, and buildings. Consideration is given to elements-at-risk both within the burned area perimeter and along its periphery. The number of elements-at-risk potentially affected by debris flow generated within the burned area will vary depending on the size of the burned area, its proximity to populated areas, and the relative location of transportation corridors.

For the 1987 Stanislaus Complex Fire, risk was established by first identifying element-at-risk within and adjacent to the fire perimeter. Debris flow risk was only assessed for those elements-at-risk where pre-fire vegetation within the drainage basins was significantly altered by the fire and coincided with evidence of past debris flow activity (De Graff and Lewis 1989). The degree of risk was determined based on professional judgement during field review of these conditions for each element-at-risk. Mitigation measures were proposed to reduce the threat posed by debris flow occurrence to locations of high risk and to locations important for public safety (e.g. a firestation) with moderate risk.

The risk assessment focus on elements-at-risk used for the Stanislaus Complex Fire was commonly employed for BAER assessments through the 1990s, which worked reasonably well for wildfires in rural areas involving a few hundred to thousands of hectares (De Graff 1994). But it proved more difficult to conduct quickly on the 59,076 ha area burned by the Stanislaus Complex Fire, the fourteenth largest fire in California (Cal Fire 2014). Elements-at-risk due to public safety issues within the burned area were swiftly evaluated in the immediate aftermath of the fire within the required 10 days after containment. Mitigation measures were identified for several drainage basins where debris flows posed a hazard to a County road near Shingle Hill (De Graff and Lewis 1989). However, nine parcels of private land with potential for property damage were not fully assessed until the end of November. This delay was necessary for aerial photo mapping of past debris flow activity and field evaluation to be completed (De Graff and Lewis 1989). While eight of the nine parcels either had a low risk or cost-effective counter-measures were not possible, timely evacuation 


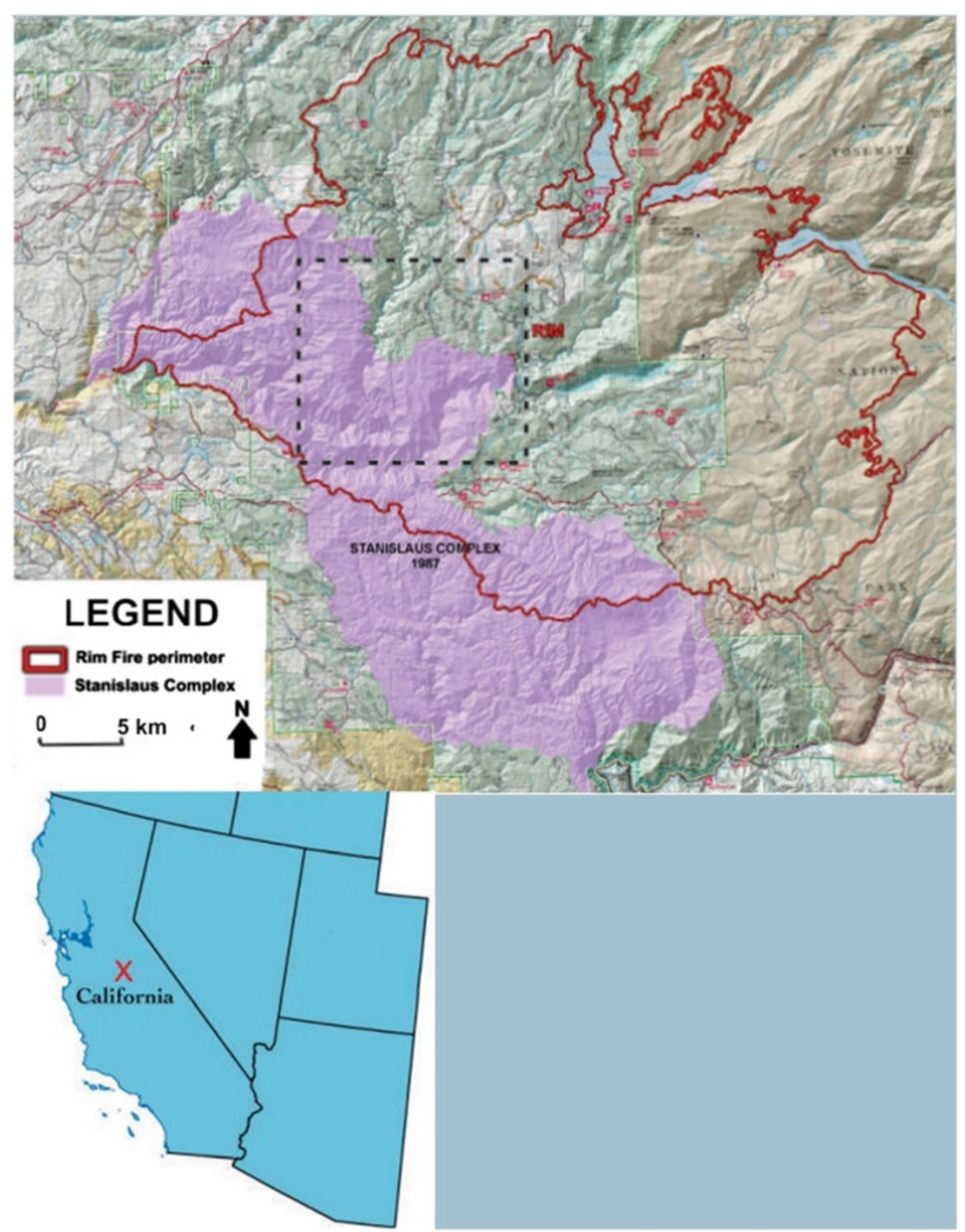

Figure 1 A map showing the location of the Stanislaus Complex and Rim Fires in the Stanislaus National Forest and Yosemite National Park in California. The area burned during the 1987 Stanislaus Complex fire is shown in purple shading and the area burned during the 2013 Rim fire is marked by the dark red line delineating the fire's perimeter. These two large wildfires occurred twenty-six years apart and affected much of the same area in the Sierra Nevada, California. The dashed line outlining a square represents the mapped area shown in Figure 3. (Courtesy of the USDA Forest Service).

during storm events was identified as a possible mitigation for the remaining parcel (De Graff and Lewis 1989).

In contrast, the risk assessment for the 2013 Rim Fire, the third largest wildfire in California, focused on the hazard throughout the entire burned area. At 104,131 ha, this wildfire was the third largest in California (Cal Fire 2014). Assessing debris flow risk began with establishing the probability of debris flow occurrence and possible volumes within every drainage basins fully or partly within the perimeter of the wildfire (Staley 2013). The relative risk for debris flow hazard for each fire-affected drainage basins was determined by combining the probabilities of occurrence and size (Staley 2013). Drainage basins with moderate or greater debris flow hazard were compared to the compiled element-at-risk by the BAER team geologists (Gallegos et al. 2013). In some instances, additional field evaluation was carried out both to verify risk and to evaluate mitigation options. Recommended mitigation to address public safety due to debris flow hazard was limited to closing Lumsden Road to public use (Gallegos et al. 2013). On March 3, 2014, inspection by Forest Service personnel found Lumsden Road partially or fully blocked 
at five locations by debris flows triggered on the burned slopes by a storm event the previous week (Figure 2) (C. Kvamme, Written Comm., March 5, 2014).

\section{The technological and scientific advances}

As described above, these fires demonstrate differences in determining the risk posed by debris flows from burned area. The focus on element-at-risk, common to earlier BAER determinations of potential debris flow risk, proved difficult to accomplish quickly and left the possibility of overlooking locations with significant risk during evaluation of areas burned by large fires. The present-day debris flow risk assessment efforts exemplified by the Rim Fire focuses on rapidly identifying the hazard levels present at drainage basins throughout the burned area. With the hazard levels defined, any elements-at-risk from debris flow occurrence can be readily identified and their risk determined. This shift in risk assessment focus and capability was achieved because of both technological advances and improved scientific understanding of post-fire debris flow occurrence during the past 30 years.

Assessing how burned drainage basins will respond to future precipitation events is key to determining a number of potential impacts due to increased runoff and erosion including the occurrence of debris flows. Within the burned area, the effect of the fire on the vegetation and surface soils creates a mosaic ranging from being unburned to experiencing complete loss of vegetation and organic ground cover combined with heat-impacted surface soil. This natural pattern of differing surface impact from the fire results from a number of factors including

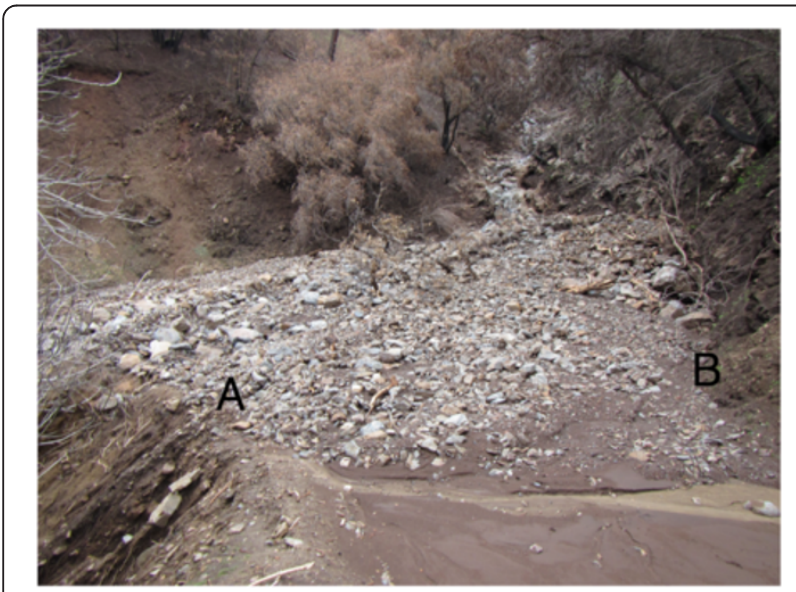

Figure 2 A photo showing one of five debris flow deposits blocking Lumsden Road, a native-surfaced Forest Service road accessing the Tuolumne River east of Groveland, California.

The photo was taken on March 3, 2014 after storm events occurred during the previous weeks. For scale, Point $\mathbf{A}$ at the outer edge of the road bed is 4.8 meters from point $\mathbf{B}$ at the inside edge of the road bed. (Courtesy of the USDA Forest Service).
1) the variability of pre-fire vegetation present, 2) the moisture levels in the organic materials at the time of the fire and 3) the influence of topography, wind, and relative humidity levels on the fire front moving over the landscape. A soil burn severity map can be constructed to display differences in the degree to which fire affected the vegetation and near-surface soils. The map delineates areas which are: unburned, low, moderate, and high soil burn severity. A precipitation event affecting a drainage basin which has only unburned and low soil burn severity areas would generate a runoff and erosional response differing little from the response prior to the wildfire. However, the pre- and post-fire responses for a drainage basin with moderate and high soil burn severity areas would be markedly different. Because the soil burn severity map is pivotal to evaluations by multiple disciplines, it is one of the first actions taken during the assessment process. Technological advances in the past 30 years have improved the quality and resolution of the burn severity data which has facilitated its quick production.

At the time of the Stanislaus Complex Fire, the initial mapping of soil burn severity was based on the fire's effect on the overstory vegetation and surface organic material using general guidelines for interpreting the proportion of green, scorched or consumed overstory and remaining organic ground cover. Producing this map commonly required helicopter overflight by a trained observer. The observer would delineate the differing areas of soil burn severity seen onto a topographic map carried during the flight. Helicopter overflights could require more than one day due to helicopter availability, weather conditions and presence of smoke. The initial soil burn severity map of the burned area was modified by altering some delineated boundaries and verifying burn severity classifications based on ground surveys at selected locations. In 1987, this method was used for preparing the soil burn severity map for the Stanislaus Complex fire (Figure 3A).

The soil burn severity map for the Rim Fire was initially derived from satellite imagery (Figure 3B). The downloaded imagery was transformed using an algorithm called the differenced Normalized Burn Ratio (dNBR) (Clark 2013), which identifies the $d N B R$ values between images taken just after the fire and 1-year earlier. The dNBR is reclassified to produce a burned area reflectance classification (BARC) of the burned area approximating soil burn severity prior to field validation (Clark 2013). Using this approach to produce soil burn severity maps became operational for USDA Forest Service BAER teams on large wildfires in 2002. While there is ongoing analysis of different sensors and imagery, BARC maps have been produced for more than 900 teams since going operational (Clark et al. 2003; Clark 2013).

The BARC map is a digital product which was incorporated into the Geographic Information Systems (GIS) 


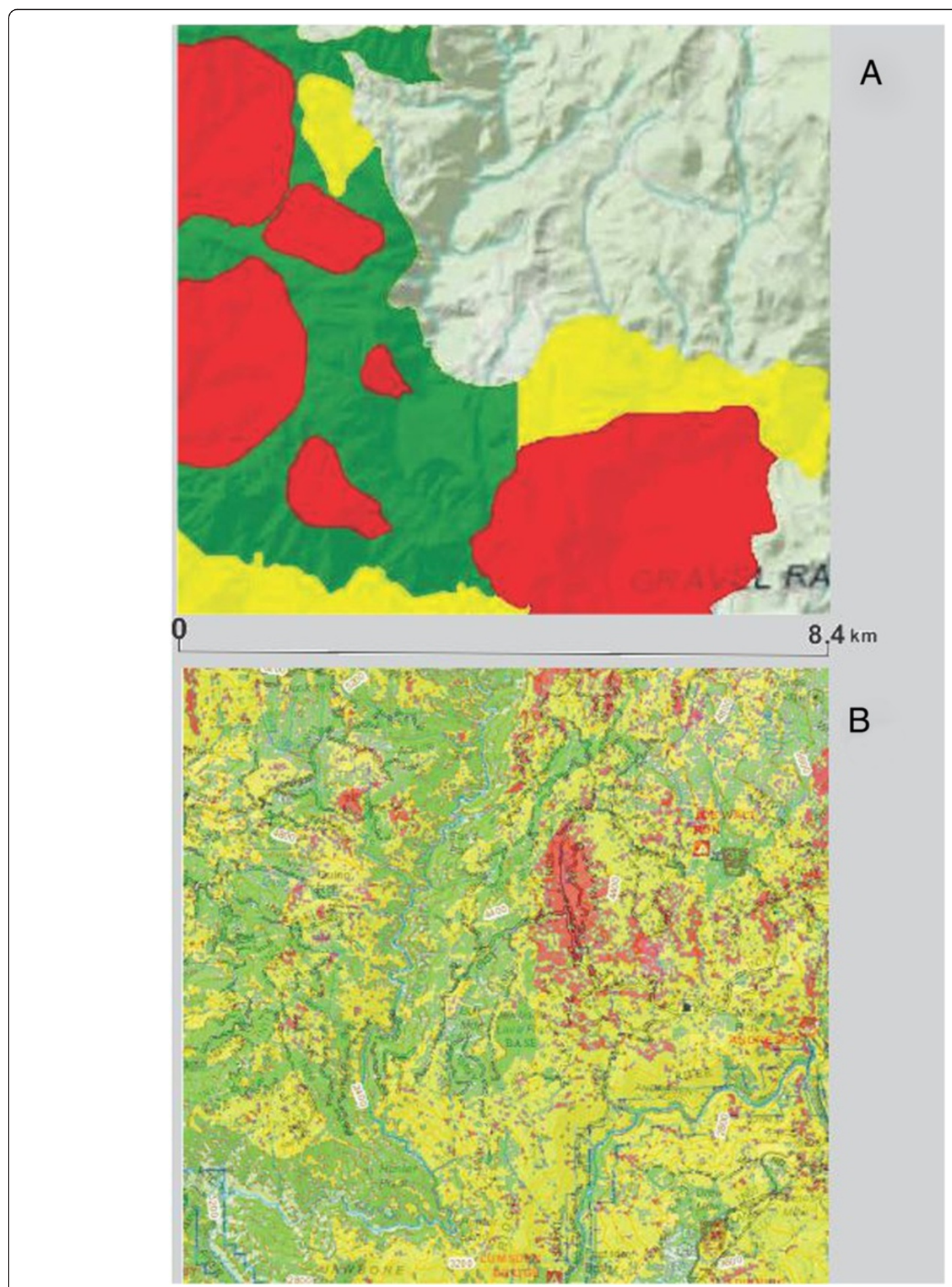

Figure 3 Two maps showing the same approximately 7,225 ha area (see Figure 1). In both maps (A and B) the soil burn severity is color-coded low (green), moderate (yellow) and high (red). Unburned areas are background map color. Map $\mathbf{A}$ is a digitized version of the soil burn severity map of the Stanislaus Complex fire which was originally hand-drawn on topographic maps for the initial burned area emergency assessment work. The large polygons are typical for observer-based interpretations. Map B is the soil burn severity map produced for the 2013 Rim Fire using burned area reflectance characterization (BARC) from satellite imagery. Burn severity polygons on this final version (modified based on spot field evaluation of soil condition) exemplifies the greater detail and resolution possible by this improved method. (Courtesy of the USDA Forest Service). 
platform for the Rim Fire. In addition to enabling the BARC map to be layered with soil maps, digital terrain model products, and land ownership, the BARC could be finalized based on field verification of classified area (Flores et al. 2013). This established the burn-affected soil conditions present within the classified vegetation changes caused by the fire and yielded the final soil burn severity map (Figure 3B). To ensure the consistency of soil interpretations collected in the field, more detailed standards were developed (Parsons et al. 2010). The Rim Fire soil burn severity map was developed for the entire burned area and shared with those entities engaged in assessment efforts outside the national forest boundaries.

Even a cursory comparison of Figure 3A and 3B highlights the greater resolution now possible using the BARC map as the initial soil burn severity map. Being able to more precisely map the soil burn severity within smaller drainage basins has facilitated modeling increased runoff, projected soil loss due to erosion, and post-fire debris flow hazard.

The scientific advance which improved defining debris flow risk was the recognition that nearly all post-fire debris flows are initiated through runoff-dominated erosion by surface overland flow rather than infiltrationtriggered failure mobilizing discrete landslide masses (Cannon 2001; Cannon et al. 2003; Cannon and Gartner 2005; Parise and Cannon 2012). During storm events, the surface runoff progressively incorporates sediment from the hillslopes and channels into the water. At some point within the channel, storm flow reaches a proportion of sediment within the water which transforms it to a debris flow (Parise and Cannon 2012; De Graff et al. 2013). In many instances, material eroded from within the channels has provided the majority of the sediment resulting in debris flow occurrence (Santi et al. 2008; Wagner et al. 2013).

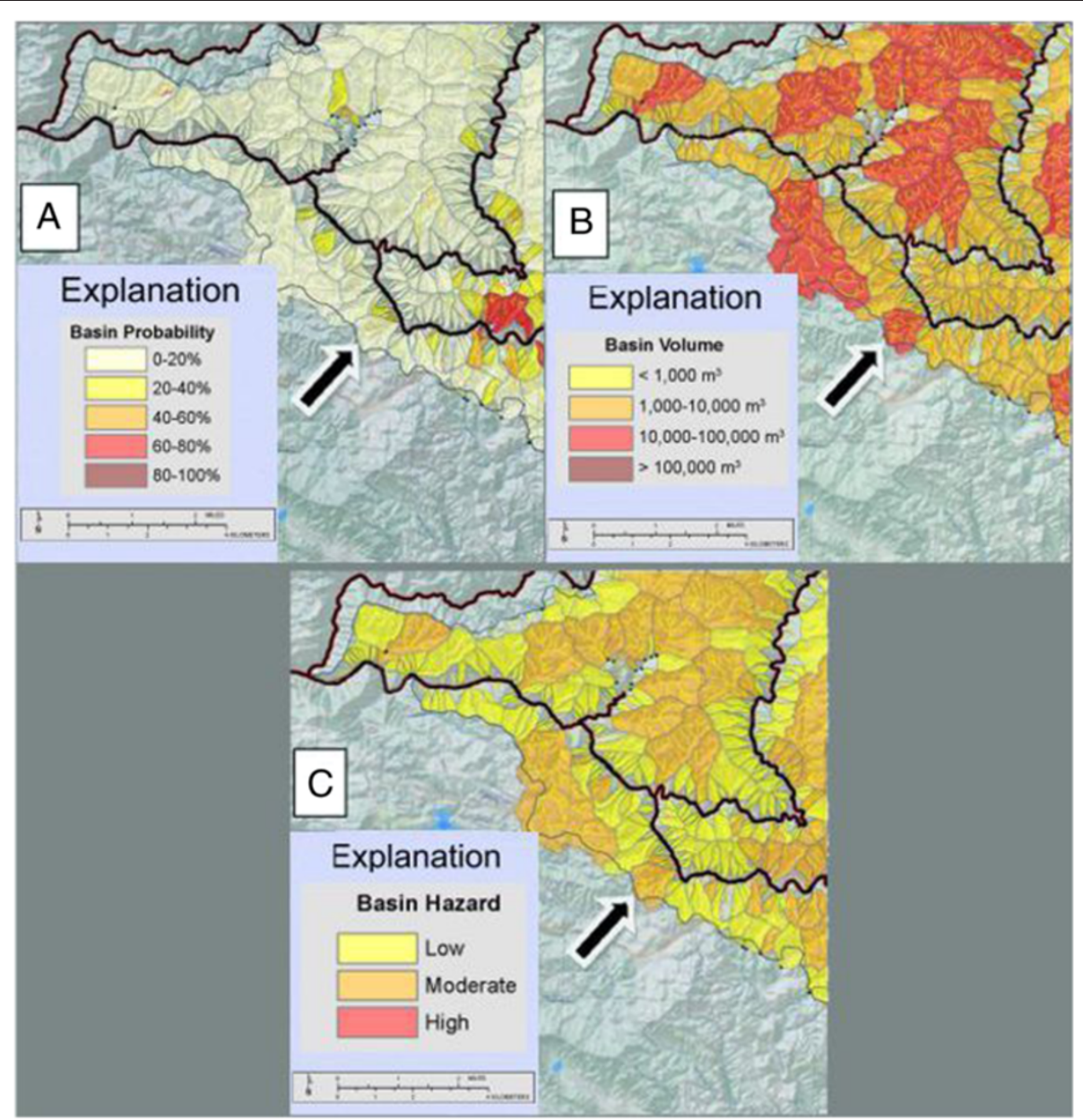

Figure $4 \mathrm{~A}$ part of the three maps produced by the U.S. Geological Survey applying the debris flow models for probability of occurrence (A) and volume (B) to the Rim fire (Staley, 2013). Map segment C is the relative hazard of post-fire debris flows representing the combination of probable occurrence and likely volume. The black arrow indicates the same drainage basin to illustrate how the moderate hazard (C) results from the $20-40 \%$ probability of occurrence (A) and the likely 10,000-100,000 $\mathrm{m}^{3}$ volume (B). The mapped area in A, B, and C is along the Tuolumne River canyon west of the area displayed in Figure 3. (Modified from Plates 1, 2 and 3 in Staley, 2013). 
Table 1 A summary how soil burn severity maps were prepared, debris flow hazard was identified, and debris flow risk assessed for the Stanislaus Complex and Rim fires

\begin{tabular}{|c|c|c|}
\hline & 1987 Stanislaus Complex Fire & 2013 Rim Fire \\
\hline Soil burn severity mapping & $\begin{array}{l}\text { Observer-based visual identification from helicopter } \\
\text { and ground-level promontories; modified by } \\
\text { random ground-level soil survey }\end{array}$ & $\begin{array}{l}\text { Computer processing of satellite imagery comparing } \\
\text { pre- and post-fire reflectance; boundaries adjusted } \\
\text { based on verification by ground-level soil survey }\end{array}$ \\
\hline $\begin{array}{l}\text { Identification of debris } \\
\text { flow hazard }\end{array}$ & $\begin{array}{l}\text { Use existing debris flow mapping or aerial-photo } \\
\text { interpreted mapping of past debris flow occurrence } \\
\text { to identify areas of potential debris flows near } \\
\text { identified elements-at-risk }\end{array}$ & $\begin{array}{l}\text { Empirical debris flow model combining identified } \\
\text { probability of occurrence and likelihood of volume } \\
\text { class to show hazard for all drainage basins present } \\
\text { in the burned area }\end{array}$ \\
\hline Assessing debris flow risk & $\begin{array}{l}\text { Professional judgment using the assumption that } \\
\text { debris flows occurrence differed little between burned } \\
\text { and unburned areas and resulted from infiltration-triggered } \\
\text { failure mobilizing discrete landslide masses }\end{array}$ & $\begin{array}{l}\text { Interpreted based on risk assessment formula using } \\
\text { modelled hazard probability and recognizes burned-area } \\
\text { debris flows are due to runoff-dominated erosion by } \\
\text { surface overland flow }\end{array}$ \\
\hline
\end{tabular}

The recognition that post-fire debris flows are initiated by runoff-dominated erosion resulted in research leading to development of empirical models for predicting the probability of debris flow occurrence and the range of possible volumes should one take place (Cannon et al. 2010). The models calculate the probability of debris flow occurrence in individual drainage basins in response to a specified storm event. The probability is a function of obtainable factors such as soil properties, measures of basin morphology, soil burn severity, and expected rainfall. Which factors to use and their integration into the model were determined through logistic regression analysis of data from 388 individual basins located within areas burned in Montana , Idaho and Colorado (Cannon et al. 2010). A companion model used for estimating the probable volume of a post-fire debris flow employed multiple linear regression analysis of data from 56 basins located within areas burned in California, Utah and Colorado (Gartner et al. 2008; Cannon et al. 2010). The volume predictions utilize basin gradient, soil burn severity extent, and storm rainfall as primary factors.

Both the probability of occurrence and likely range of volumes are predicted at the basin outlet. Expected rainfall conditions affecting the recently burned area is incorporated in the debris flow models as a critical factor (Cannon et al. 2008; Kean et al. 2011; Staley et al. 2013).
Verification of the models compared predicted and actual results for a dataset of 21 post-fire debris flows reported in the literature and not used in developing the models (Cannon et al. 2010). It was recognized during model development that most debris flows happen in small basins as represented by the $1.7 \mathrm{~km}^{2}$ mean and $0.2 \mathrm{~km}^{2}$ median values for the basins in the dataset (Cannon et al. 2010). The empirical basis for these models means that continuing growth of the datasets for post-fire debris flows can refine the factor relationships and improve future predictive capability (Staley et al. 2013).

The Rim Fire demonstrates how the better understanding of their initiation during storm events and technological advances in collecting relevant data enabled quantification of post-fire debris flow risk. This is illustrated by application of the probability and volume models, which used data from the soil burn severity map, to show relative hazard of post-fire debris flows (Staley 2013). Figure 4 shows the results for an area east of Groveland, California near the point of origin for the Rim fire. Three maps are produced: 1) probability of occurrence, 2) probability of volume range, and 3) combined hazard. Combined hazard integrates the likelihood of occurrence with the probability of a particular volume range. Greater hazard is ascribed to higher probabilities of occurrence resulting in larger debris flows. The hazard determination is defined drainage

Table 2 A qualitative assessment of how soil burn severity mapping, debris flow hazard identification and debris flow risk determination differed between the Stanislaus Complex and Rim fires

\begin{tabular}{lllll}
\hline & & Soil burn severity mapping & Identification of debris flow hazard & Assessing debris flow risk \\
\hline Data type & 1987 & Qualitative & Qualitative & Qualitative \\
& 2013 & Quantitative & Quantitative & Quantitative \\
Precision & 1987 & Low & Low to moderate & Moderate \\
& 2013 & High & High & High \\
Consistency & 1987 & Low to moderate & Moderate & Moderate \\
Completed within & 2013 & High & High & High \\
BAER time constraint & 1987 & Yes & No & No \\
\hline
\end{tabular}


basin outlet. The model was applied to 1,238 drainage basins ranging in size from 0.2 to $16.4 \mathrm{~km}^{2}$ affected by the Rim fire (Staley 2013).

Staley (2013) used a 10-yr storm event for the area in which the 60-minute rainfall accumulations would range between $22.8 \mathrm{~mm}$ and $29.0 \mathrm{~mm}$ in model computations. These values represent rainfall rates exceeding values associated with post-fire debris flows occurring in southern California and the intermountain western United States. The maps are generated using GIS technology, which facilitates the models use of the soil burn severity map as a data source, enables quick comparison to GIS layers containing data on potential elements-at-risk present, and permits transmission of the model results to the geologists conducting the initial post-fire debris flow risk assessment (Staley 2013; Gallegos et al. 2013).

\section{Conclusions}

Stanislaus Complex and Rim fire represent the end points for the approaches to assessing debris flow risk for postwildfire emergency response during the last 30 years. Because it involves much of the same terrain, the variables influencing post-fire debris flow occurrence and the elements-at-risk which are threatened are very similar. Comparison of the post-fire debris flow risk assessment for the two fires provides qualitative evidence of the benefits of greater quantification of risk. Table 1 summarizes the changes in scientific understanding and technological methods during the last 30 years resulting in a more rapid and thorough assessment of debris flows after a wildfire.

While no individual metric can quantitively demonstrate the improved risk assessment, there are qualitative data supporting this conclusion (Table 2). Data used in assessing the debris flow hazard and soil burn severity conditions across the burned area, a key factor, are now quantifiable data. Similarly, this data are determined with greater precision and consistency. Perhaps, one of the most telling points is that the development of the soil burn severity map, identification of debris flow hazard areas, and determination of debris flow risk was determined for the Rim fire within the time period required for initial assessment. This was achieved despite the Rim fire having affected an area 1.75 times larger than the Stanislaus Complex fire.

As noted earlier, the completed assessment of debris flow risk for the Stanislaus Complex fire required an additional eight weeks. Even with this additional time, the completed risk assessment was not only limited to a qualitative judgement, but also less precise and consistent (Table 2). It is also worth noting that true risk assessment as conventionally defined requires that the probability of a hazard be determined. Consequently, the post-fire debris flow risk assessment for the Stanislaus Complex, while adequate for its time, was more an identification of relative debris flow susceptibility reflecting spatial hazard differences rather than an actual assessment of risk.

The increased number of large wildfires in proximity to expanding population centers in the western United States poses a greater risk both from the direct effect of the fire and subsequent floods and debris flows. During the last 30 years, scientific and technological advances have resulted in the ability to better quantify risk and its underlying components. This improved assessment of post-fire debris flows is also carried out more rapidly. Improved, rapid risk assessment of post-fire debris flows provides emergency response planners and others responsible for public welfare with the opportunity to counter this increased risk through more effective mitigation prior to initiating storm events.

\section{Abbreviations}

BAER: Burned Area Emergency Response; BARC: Burned Area Reflectance Classification; dNBR: Differenced Normalized Burn Ratio; GIS: Geographic Information Systems; USDA: U.S. Department of Agriculture.

\section{Acknowledgements}

The author wishes to acknowledge the many fellow BAER team members who he has worked with on 36 wildfires during the last 32 years for providing the experiential knowledge for this paper. An oral version of this paper was presented in the technical session, "Geomorphology and Hydrology Impacts from Wildfires: Advances in Our Understanding Over the Last 50 Years", during the 2013 Geological Society of America annual meeting in Denver, Colorado. This paper benefits from an extended discussion session included after the presentations. Mr. Doug Sprinkel, Utah Geological Survey, was kind enough to apply his well-developed editorial skills to an earlier version of this paper. He provided comments and suggestions which materially improved its readability. The final manuscript is both clearer and more detailed thanks to the many thoughtful and detailed comments and suggestions provided by two anonymous reviewers.

Received: 18 June 2014 Accepted: 24 September 2014

Published online: 04 November 2014

\section{References}

Brown TJ, Hall BL, Westerling AL (2004) The impact of twenty-first century climate change on wildland fire danger in the western United States: an applications perspective. Clim Change 62:365-388

Calcaterra D, Parise M, Strumia S, Mazzella E (2007) Relations between fire, vegetation and landslides in the heavily populated metropolitan area of Naples, Italy. In: Schaefer VR, Schuster RL, Turner AK (eds) Proc. $1^{\text {st }}$ North Amer. Landslide Conf., Vail (Colorado), AEG sp. publ. 23. Denver, Association of Environmental \& Engineering Geologists, pp 1448-1461

Cal Fire (2014) Top 20 largest California wildfires. http://www.fire.ca.gov/ communications/downloads/fact_sheets/20LACRES.pdf. Accessed 16 June 2014

Cannon SH, Powers PS, Savage WZ (1998) Fire-related hyperconcentrated and debris flows on Storm King Mountain, Glenwood Springs, Colorado, USA Environ. Geology 35(2-3):210-218

Cannon SH (2001) Debris-flow generation from recently burned watersheds. Environ Eng Geosci 7(4):321-341

Cannon SH, Kirkham RM, Parise M (2001) Wildfire-related debris-flow initiation processes, Strom King Mountain, Colorado. Geomorphology 39(3-4):171-188 Cannon SH, Gartner JE, Parret C, Parise M (2003) Wildfire-related debris-flow generation through episodic progressive sediment bulking processes, western USA. In: Rickenmann D, Chen C (eds) Debris-Flow Hazards Mitigation: Mechanics, Prediction, and Assessment, Proc. $3^{\text {rd }}$ Int. Conf., Davos (Switerland), vol 1. Rotterdam, Millpress, pp 71-82

Cannon SH, Gartner JE (2005) Wildfire-related debris flow from a hazards perspective. In: Jakob M, Hungr O (eds) Debris-flow hazards and related phenomena. Springer, Berlin 
Cannon SH, Gartner JE, Wilson RC, Bowers JC, Laber JL (2008) Storm rainfall conditions for floods and debris flows from recently burned areas in southwestern Colorado and southern California. Geomorphology 96:250-269

Cannon SH, DeGraff J (2009) Incorporating spatial, temporal, and climate variability into tools for assessing post wildfire debris-flow hazards. In: Sassa K, Canuti P (eds) Landslides_Disaster Risk Reduction. Springer, Heidelberg

Cannon SH, Gartner JE, Rupert MG, Michael JA, Rea AH, Parrett C (2010) Predicting the probability and volume of postwildfire debris flows in the intermountain western United States. Geol Soc Am Bull 122(1-2):127-144

Cannon SH, Boldt EM, Laber JL, Kean JW, Staley DM (2011) Rainfall-intensity-duration thresholds for postfire debris-flow emergency-response planning. Nat Hazards 59:209-236

Clark J, Parsons A, Zajkowski T, Lannon K (2003) Remote sensing imagery support for burned area emergency response teams on 2003 southern California wildfires. Remote Sensing Application Center RSAC-2003-RPT1, USDA Forest Service, Salt Lake City

Clark J (2013) Remote sensing and geospatial support to burned area emergency response (BAER) teams in assessing wildfire effects to hillslopes. In: Margottin C, Sassa K, Canuti P (eds) Landslide Science and Practice. Global Environmental Change, vol 4. Springer, Heidelberg, pp 211-215

De Graff JV, Lewis DS (1989) Using past landslide activity to guide post-wildfire mitigation. In: Watters RJ (ed) Engineering Geology and Geotechnical Engineering, 25th Symposium on Engineering Geology and Geotechnical Engineering, Reno, NV, March 1989. Balkema, Rotterdam p, p 65

De Graff JV (1994) The geomorphology of some debris flows in the southern Sierra Nevada, California. Geomorphology 10:231-252

De Graff JV, Cannon SH, Gallegos AJ (2007) Reducing post-wildfire debris flow risk through the Burned Area Emergency Response (BAER) process. In: Schaefer VR, Schuster RL, Turner AK (eds) Proc. 1st North Amer. Landslide Conf., Vail (Colorado), AEG sp. publ. 23. Denver, Association of Environmental \& Engineering Geologists, pp 1440-1447

De Graff JV, Wagner D, Gallegos AJ, DeRose M, Shannon C, Ellsworth T (2011) The remarkable occurrence of large rainfall-induced debris flows at two different locations on July 12, 2008, Sierra Nevada, CA. Landslides 8(3):343-353

De Graff JV, Gallegos AJ (2012) The Challenge of Improving Identification of Rockfall Hazard after Wildfires. Environ Eng Geosci 18(4):389-397

De Graff JV Gallegos AJ (2013) Observations demonstrating the runoff-initiation of the July 12, 2008 Piute wildfire debris flows. Sierra Nevada, California, https://gsa.confex.com/gsa/2013CD/webprogram/Paper218857.html

De Graff JV, Cannon SH, Parise M (2013) Limiting the immediate and subsequent hazards associated with wildfires. In: Margottini C, Kyoji S, Canuti P (eds) Landslide Science and Practice, vol 4, Global Environmental Change. Springer, Heidelberg, pp 199-209

Flores M, Kvamme C, Rust B, Takenaka K, Young D (2013) BAER Assessment Soils Report, Rim Fire (Stanislaus NF). USDA Forest Service, Available via http://inciweb.nwcg.gov/photos/CASTF/2013-09-06-1648-Rim-PostFireBAER/related_files/pict20130830-204315-0.pdf. Accessed 16 June 2014

Gallegos A, Schwartz J, Annis D, De Graff J (2013) Geology, Rim Fire BAER (Stanislaus NF). USDA Forest Service, Available via http://inciweb.nwcg.gov/ photos/CASTF/2013-09-06-1648-Rim-PostFire-BAER/related_files/ pict20130830-204156-0.pdf. Accessed 16 June 2014

Garćia-Ruiz JM, Arnáez J, Gómez-Villar A, Ortigosa L, Lana-Renault N (2013) Fire-related debris flows in the Iberian Range, Spain. Geomorphology 196:221-230

Gartner JE, Cannon SH, Santi PM, deWolfe VG (2008) Empirical models to predict the volumes of debris flows generated by recently burned basins in the western U.S. Geomorphology 96:339-354

Giraud RE, McDonald GN (2007) The 2000-2004 fire-related debris flows in northern Utah. In: Schaefer VR, Schuster RL, Turner AK (eds) Conference Presentations, $1^{\text {st }}$ North American Landslide Conference, Vail, CO, AEG Special Publication No. 23. Denver, Association of Environmental \& Engineering Geologists, pp 1522-1531

Gorte RW, Vincent CH, Hanson LA, Rosenblum MR (2012) Federal Land Ownership: Overview and Data, Congressional Research Service 7-5700. Available via: https://www.fas.org/sgp/crs/misc/R42346.pdf. Accessed 16 June 2014

Inbar M, Tamir MI, Wittenberg L (1998) Runoff and erosion processes after a forest fire in Mount Carmel, a Mediterranean area. Geomorphology 24(1):17-33

Jordan P, Covert SA (2009) Debris flows and floods following the 2003 wildfires in southern British Columbia. Environ Eng Geosci 15(4):217-234
Kean JW, Staley DM, Cannon SH (2011) In situ measurements of post-fire debris flows in southern California: Comparisons of the timing and magnitude of 24 debris-flow events with rainfall and soil moisture conditions. J Geophys Res F: Earth Surf 116(F4)

Keeley JE, Fotheringham CJ, Morais M (1999) Reexamining fire suppression impacts on brushland fire regimes. Science 284(5421):1829-1832

McCaffrey S (2004) Thinking of wildfire as a natural hazard. Soc Nat Res 17:509-516

Moody JA, Shakesby RA, Robichaud PR, Cannon SH, Martin DA (2013) Current research issues related to post-wildfire runoff and erosion processes: Earth Sci Rev. doi:10.1016/j.earscirev.2013.03.004

Murnane RJ (2006) Catastrophe risk models for wildfires in the wildland-urban interface: what insurers need. Nat Hazard Rev 7(4):150-156

NASA (2011) Earth Observatory. National Aeronautic and Space Administration, Washington, http://earthobservatory.nasa.gov/GlobalMaps/view.php? d1=MOD14A1_M_FIRE. Accessed 16 June 2014

Nyman P, Sheridan PJ, Smith HG, Lane PNJ (2011) Evidence of debris flow occurrence after wildfire in upland catchments south-east Australia. Geomorphology 125:383-401

Parise M, Cannon SH (2012) Wildfire impacts on the processes that generate debris flows in burned watersheds. Nat Hazards 61:217-227

Parsons A, Robichaud PR, Lewis SA, Napper C, Clark JT (2010) Field guide for mapping post-fire soil burn severity. General Technical Report RMRS-GR-243. USDA Forest Service, Washington

Pierson TC (2005) Hyperconcentrated flow-transitional process between water flow and debris flow. In: Jakob M, Hungr O (eds) Debris-flow Hazards and Related Phenomena. Berlin, Springer, pp 159-202

Radeloff VC, Hammer RB, Stewart SI, Fried JS, Holcomb SS, McKeefry JF (2005) The wildland urban interface in the United States. Ecol Appl 15:799-805

Restrepo P, Jorgensen DP, Cannon SH, Costa J, Laber J, Major J, Martner B, Purpura J, Werner K (2008) Joint NOAA/NWS/USGS prototype debris flow warning system for recently burned areas in southern California. Bull Am Meteorol Soc 89:1845-1851

Santi PM, deWolfe VG, Higgins JD, Cannon SH, Gartner JE (2008) Sources of debris flow material in burned areas. Geomorphology 96:310-32

Santi PM, Hewitt K, VanDine DF, Cruz EB (2011) Debris-flow impact, vulnerability, and response. Nat Hazards 56(1):371-402

Santi P, Cannon S, DeGraff J (2013) Wildfire and Landscape Change. In: Shroder JF (ed) Treatise on Geomorphology, vol 13. Academic Press, San Diego, pp 262-287

Shakesby RA, Doerr SH (2006) Wildfire as a hydrological and geomorphological agent. Earth Sci Rev 74:269-307

Staley DM, Kean JW, Cannon SH, Schmidt KM, Laber JL (2013) Objective definition of rainfall intensity-duration thresholds for the initiation of post-fire debris flows in southern California. Landslides 10(5):547-562

Staley DM (2013) Emergency assessment of post-fire debris-flow hazards for the 2013 Rim Fire, Stanislaus National Forest and Yosemite National Park, California. Open-File Report 2013-1260, U.S. Geological Survey, Washington

Van Westen CJ, van Asch TWJ, Soeters R (2006) Landslide hazard and risk zonation-why is it still so difficult? Bull Eng Geol Env 65:167-184

Varnes DJ (1984) Landslide hazard zonation: a review of principles and practice. UNESCO, Paris

Wagner D, De Graff JV, Lancaster J (2013) Debris flows in the southern and eastern Sierra Nevada region, California. In: Putirka K (ed) Geologic Excusrions from Fresno, California, and Central Valley: A Tour of California's Iconic Geology, Field Guide 32. Geological Society of America, Boulder, pp 99-128

Westerling AL, Hidalgo HG, Cayan DR, Swetnam TW (2006) Warming and earlier spring increase western US forest wildfire activity. Science 313(5789):940-943

doi:10.1186/s40677-014-0005-2

Cite this article as: De Graff: Improvement in quantifying debris flow risk for post-wildfire emergency response. Geoenvironmental Disasters 2014 1:5. 